\title{
New Methodological Approaches in Solving Certification Problem of Historical Solid Radioactive Waste Sent for Burial from Chornobyl Nuclear Power Plant
}

Keywords:

radioactive waste,

Chornobyl NPP,

specific activities,

difficult-to-measure radionuclides,

key nuclides,

certification,

scaling factor.

\begin{abstract}
Two methodological approaches for radioactive waste (RAW) certification used in RAW management systems in Italy and France, are addressed. Their applicability was assessed in solving certification problem of historical waste accumulated at the Chornobyl NPP in comparison with the standard methods recommended by the IAEA. Testing new methodological approaches was carried out on the example of solid RAW (SRW) of operational origin, which were previously studied for the content of 24 radionuclides within their composition. The procedures for testing researchable methods have used the criteria for SRW acceptance for burial valid in SRW Treatment Plant, which met their current provisions and those ones planned for approval. It was established that the use of quantitative criteria applied in the algorithms of studied methodological approaches for radwaste certification can significantly reduce overestimation degree of summary activity of waste packages by way of removing from the list of difficult-to-measure radionuclides, whose presence can be neglected in view of negligible risk of exceeding the activity limits established for them. The methodological approaches addressed in this work allow optimizing radionuclide contents subject to mandatory measurement, or calculated determination of their activity in waste packages, and can be recommended to solve the problems when characterizing ChNPP's historical waste transported for their final disposal.
\end{abstract}

\section{Introduction}

The radiological characterization plays an important role when decommissioning nuclear facilities and is crucial in planning, implementing and optimizing the decommission projects [1]. Effective characterization allows determining the extent and nature of contamination, providing the most important evidence to support facility dismantling, management of producible materials and wastes, protection of workers, public and environment, and associated costs estimates.

The disposal of radioactive waste requires the knowledge of its radioactivity content in terms of specific radionuclide concentrations [2]. This information is used by the repository operator and/or regulatory body to trace radio- nuclide inventories and concentrations, which are generally limited by the safety assessment of repository and available operation license. The regulations for transfer and final disposal of radioactive waste require that the inventory of radionuclides for each package enclosing such waste were estimated and declared. The specific activities are then compared to the acceptance limits of national agencies for waste management. The waste producers must ensure that these limits were respected and distribution of quantities of interest were estimated. To date, the management of solid radioactive waste (SRW) in the Exclusion Zone of State Specialized Enterprise "Chornobyl Nuclear Power Plant" (SSE "ChNPP") sent for burial in a specially equipped near-surface repository for solid radwaste (SESRSRW) is regulated by waste acceptance Criteria [3].

(c) O. V. Mykhailov, V. M. Bezmylov 
The characterization of SRW is a comprehensive task, especially when historical waste is involved. According to [2], the historical wastes are those, which have been stored for a long period before their characterization. Currently, this type of ChNPP wastes accumulated over normal work period of its power Units, is being stored in the Building No 85 of Repository for SRW (RSRW) [4]. The rules for SRW management valid in Exclusion Zone [3] require identifying radionuclide content of each package (batch) of wastes coming for its disposal with determining specific and total activity of controllable radionuclides. At the next stage of monitoring, specific and total activities of all controllable radionuclides in packages are compared to their permissible limits, and then they are checked for non-exceeding of their ratio sums in relation to the established criteria. The French National Agency for Radioactive Waste Management (ANDRA) uses a similar approach to assess the hazard of packages and a special term for this sum, called as IRAS from the French abbreviation: Indice Radiologique d'Acceptation en Stockage (Radiological Acceptance Index in Storage) [5, 6].

Today, the list of radionuclides subject to declaration in the ChNPP SRW consists of 25 nuclides [3]. According to information available, the next version of Criteria (revision 6) [7], which is now at its consultation phase, will contain a list of 38 radionuclides to be declared in the certificate for each waste package sent for burial. Many of these relevant radionuclides cannot be measured directly by nondestructive methods in radioactive waste packages. According to [8], each nuclide of radionuclide inventory is classified as follows:

Easy-to-Measure (ETM) nuclides, such as $\gamma$-emitters, which can be measured via non-destructive nuclear assay (e. g., in-situ $\gamma$-spectrometry);

Difficult-to-Measure (DTM) nuclides, such as pure- $\beta$ emitters, which cannot be measured via non-destructive techniques (e. g., they require radiochemical analysis of samples);

Impossible-to-Measure (ITM) nuclides, such as $\alpha$-emitters, pure- $\beta$ and low-energy X-emitters, whose measurement is very difficult, and therefore, which are quantified via simulations or calculations.

From the ETMs list, the dominant $\gamma$-emitter, which is called Key Nuclide (KN) or tracer, should be selected. The $\mathrm{KN}$ is a nuclide, which is systematically measured in each single waste package, with a relative long half-life (years or dozens of years) and whose activity can be correlated to DTM and ITM nuclide activities. When the radionuclide inventory is available, the activity of DTM nuclides with using so-called Scaling Factors method (SF, [9]) should be evaluated, and calculations performed to estimate ITM nuclide activities with using Correlation Factor method (CF, [10]). The SFs and CFs are specific for each nuclear facility, operational regime, radioactive waste stream and DTM/KN nuclide pairs [2].

The experience accumulated underway nuclear installation decommissioning, for example [6, 11-14], demonstrated that it is difficult to predict the nuclide content in very low-level, low- and intermediate-level SRW by purely theoretical methods due to physical and chemical processes involved in waste generation. In addition, experimental measurements of nuclide contents are the only tool for testing any theoretical predictions [2]. In practice, the procedure of empirical determination of SF values includes the sampling and laboratory determination of radionuclide contents in the waste, statistical analysis of experimental data and selection of KN based on evidence of correlation between the DTM and $\mathrm{KN}$ nuclide activities [2, 13]. If a correlation is not found, so-called "Mean Activity Method" (MAM) can be applied for SF estimation $[2,15]$.

Finally, after a waste package is monitored by a $\gamma$-spectrometric system, DTM or ITM activities in this package are then calculated by multiplying the measured $\mathrm{KN}$ activity by SF or CF values. The resulting specific activities of controllable radionuclides are compared to the limits given by national regulatory bodies for waste management to check for waste acceptability in the storage facilities. In our case, the acceptance criteria for burial [3] are relevant ones. In the Fig. 1 taken as a reference from [6], the main stages of radiological characterization process of SRW are reflected.

However, for historical waste, another problem occurs when certifying DTM or ITM nuclide activities in the wastes sent for burial. It is as follows. A number of studies, for example $[4,6,14-16,17]$, have shown that the activity levels of a large number of DTM nuclides in historical waste often may be at or below the detection limits (DL or MDA - minimum of detectable activity). The presence of samples with such low levels of DTM activity of nuclides in the waste complicates significantly the statistical analysis of laboratory control data and the quantitative determination of corresponding SF values. Application of the MAM method, which is used in many countries for evaluation of such results [2], allows estimating the upper limit only of expected specific activity levels of DTM nuclides in a package. This method of certification leads to a significant overestimation of total activity of these nuclides in the batch sent for burial. In the event when this DTM nuclide belongs to the radionuclides with 
low limits on their total activity, such a circumstance can lead to reduction of storage capacity, and therefore, to their ineffective use.

In the recent years, the attention of a number of researchers in various countries has been paying to improvement of efficiency of RAW radiological characterization during nuclear installations decommission, development of algorithms allowing a balanced approach to the determination of optimal composition of declared radionuclides and, in particular, to identify more accurately the total activity of waste packages sent for burial (for example $[1,6,11,12,14,15]$ ).

The current Criteria [3] provided for an algorithm for comparing the characteristics of ETM and DTM nuclide activity with the limits for maximum specific and total activity in the package. Unfortunately, in addition to the provision that the methods and techniques used to determine radionuclide composition should ensure the determination of alpha- and beta-emitting radionuclides with activity above the indicated lower bound of definition, the Criteria [3] do not provide a clear indication of the basis, on which the decision is made on "zero declaration" of radionuclide activity, i. e. indication in certificate of symbol "-" instead of numerical value, when according to measurement results the radionuclide activity is less than MDA. It should be noted that in France the practice of using IRAS is not limited to checking only that its critical values are not exceeded. If a radionuclide contributes to more than $1 \%$ of IRAS, its specific activity is to be measured (direct measurement of ETM and use of SFs for DTM), otherwise it is estimated with using the Correla- tion Method (CF for ITMs) [6]. In [14], quantitative criteria were proposed, which, according to their developers, are quite appropriate to use when deciding on the presence or absence of DTM radionuclide content in waste and choosing the appropriate form for declaring their activity in the package certificate. Such an algorithm is of particular relevance for low activity levels of desired radionuclide in waste (below or slightly above the DL), when it becomes difficult to determine the exact value of SF.

The purpose of this article is to summarize new methodological approaches to certify low-level radionuclides in radioactive waste, as well as to present the results of their pilot use for historical solid waste from the Chornobyl NPP, taking into account the current and planned criteria for SRW acceptance for burial.

\section{Objects and methods}

The object of our research is historical SRW, which was generated before 1986 accident and which was stored in the Chornobyl SESRSRW. It is planned to bury this waste after determination of radiation hazard levels based on the results of monitored content of radionuclides in accordance with current criteria [3]. The subject of this work is consideration of two methods, which have not yet been used to characterize the Chornobyl SRW, but which can be useful to solve the problems associated with the certification of low-activity DTM nuclides in their composition. Hereinafter, for easy comparison of data obtained as result of their application, they are called as Method 1 and Method 2.

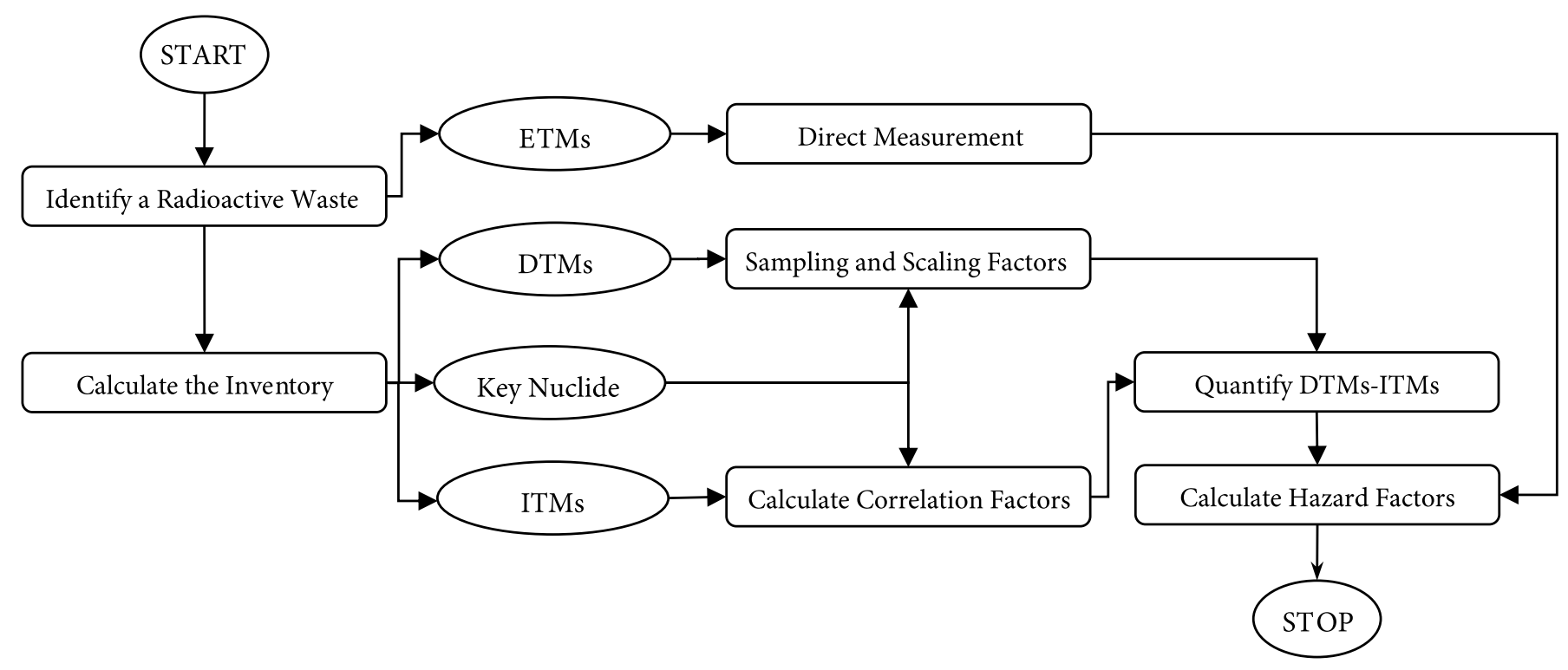

Fig. 1. The main stages of process for SRW radiological characterization 
Determination of SF value method for low level Difficult-To-Measure nuclides in waste (Method 1). The description of this method is given as based on the materials presented in [14], which analyzes the practical activities associated with the management of low-level SRW produced during the operation of nuclear power plants and nuclear installations in Italy. The main attention in this work is paid to the problem of correct determination of SF for DTM nuclides, which makes it possible to estimate the levels of nuclide contamination of various materials and split them into different waste streams. This is important, especially when it is necessary to compare the measured data to activity limit (for example, clearance levels) to make appropriate decisions about the choice of technology for their treatment or burial. The presence of very low concentrations (specific activity) of radionuclides in waste makes it difficult to identify corresponding SF from the measurement data. At the same time, the use of MAM recommended by the IAEA for the results below DL leads to a deliberately overestimated activity of DTM nuclides in waste packages. The SF assessment method proposed in [14] is intended to assist in making a decision to confirm or exclude the presence of radionuclides when verifying the compliance with activity limits with using the example of clearance levels (see the Fig. 2).

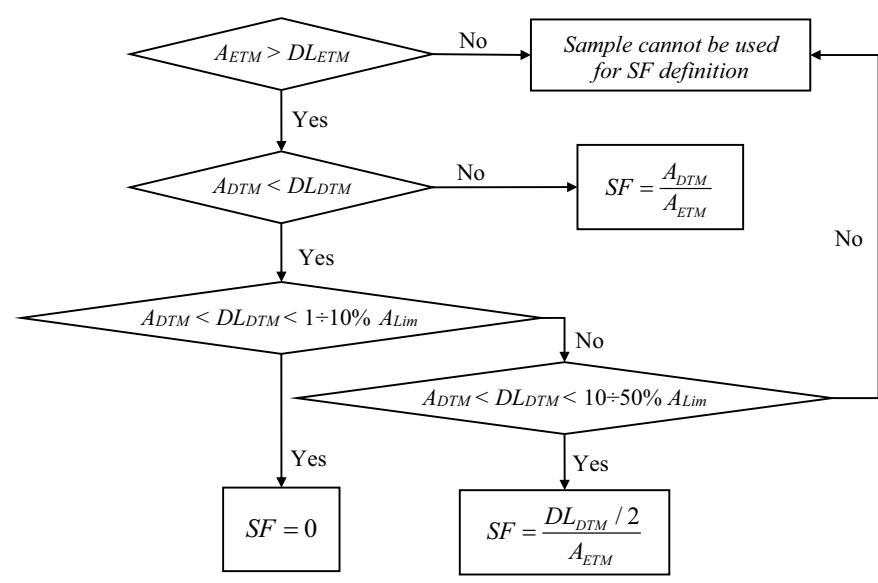

Fig. 2. Scaling factors' decision flow chart:

$A_{E T M}$ and $A_{D T M}-$ specific activity of ETM and DTM nuclides, respectively; $\mathrm{DL}_{\mathrm{DTM}}$ and $\mathrm{A}_{\mathrm{Lim}}$ - detection limit and activity limit for DTM nuclide, respectively

The algorithm shown schematically in the Fig. 2 provides, along with the use of well-known standard procedures for calculating SF, assigning its zero or non-zero values, depending on which proportion (in percent) of established activity limit (reference level) is the DL value for a specific DTM nuclide. When illustrating the algorithm proposed in [14], instead of "Nuclide concentration" sym- bol, which was given in the original text, the symbol "Specific activity of a nuclide" was used in the elements of block diagram. In the case when DTM nuclide activities exceed the DL, in identifying the SF it is proposed to use methodological guidelines, such as $[2,9]$, based on the calculation of its average value (arithmetic mean and geometric (logarithmic) mean). It is known that the arithmetic mean will tend to give a conservative value, while the geometric mean will tend to give a more representative mean when the data is distributed over several orders of magnitude. Logarithm regression can also be used to estimate the SF. The choice of one or another method for assessing the SF is widely presented in IAEA documents and scientific publications, for example [2, 4-6, 9, 11-13, 15]. In our case, the most interesting is the part of algorithm that allows obtaining SF values for DTM of nuclides, whose activity is below DL.

The application of developed algorithm shall be based on the following requirements:

in all samples taken for SF assessment, one ETM radionuclide at least must be detectable, and it shall be used as a $\mathrm{KN}$;

the detection limit must be correctly determined as based on current regulatory documentation or on the basis of procedure described in ISO11929 standard [18];

if according to the measurement results the activity of some DTM nuclide in samples is below $\mathrm{DL}_{\mathrm{DTM}}$ and at the same time DL value does not exceed $10 \%$ of corresponding activity limit (clearance level), the presence of DTM nuclide in the waste can be excluded;

if according to measurement results the activity of any DTM nuclide in samples is below $\mathrm{DL}_{\text {DTM, }}$, but the latter is within the range of $10-50 \%$ of corresponding activity limit, the presence of such DTM nuclide in the waste is impossible to exclude. It is necessary to use a non-zero SF value estimated for the case when the DTM activity of a nuclide has a rectangular distribution within the range of $0-\mathrm{DL}_{\mathrm{DTM}}$, and its average value is $\mathrm{DL}_{\mathrm{DTM}} / 2$ (a more cautious assumption from radiation protection point of view).

Within the framework of our study, above methodological approach was tested on real data obtained by us for ChNPP SRW [16]. To confirm or reliably exclude any presence of DTM nuclide in the characterized waste with activity limits proposed in $[3,7]$, the DL values (MDA) were compared to DTM nuclides, whose content in all samples, according to measurement results, was below the DL declared in laboratory report (ITM nuclides).

The test results were compared to the data obtained by standard procedure $[2,9,16]$ with identifying contribution to total activity of each radionuclide subject to certification. The total activity was determined with using the example of 
a SRW package in container form with 15-ton maximum weight. In our example, summary activity of radionuclides to be indicated in package certificate, was estimated for SRW with a mass equal to 6.444 tons. This value corresponds to its maximum value, based on capacity of empty container weighting 6.6 tons and cement mortar mass $(1,956 \mathrm{~kg})$, which is used according to procedure for RAW preparation before its burial.

To identify nuclide group contribution to summary activity, the nuclides were split as follows: ${ }^{137} \mathrm{Cs}$ and ${ }^{60} \mathrm{Co}$ - to ETM nuclides; ${ }^{90} \mathrm{Sr},{ }^{94} \mathrm{Nb},{ }^{241} \mathrm{Am},{ }^{14} \mathrm{C},{ }^{3} \mathrm{H},{ }^{235} \mathrm{U}$ and ${ }^{238} \mathrm{U}-$ to DTM nuclides and all other nuclides, whose activities according to measurement results were below the DL, - to ITM nuclides. To estimate the contribution of nuclides from ITM nuclide group, relevant DL (MDA) value was taken into account.

Method for assessment of wastes acceptability and their hazard factors by IRAS value (Method 2). The hazard factor, called IRAS was introduced by the French National Radioactive Waste Management Agency (ANDRA) to quantify the acceptability of waste packaging for disposal [6]. The IRAS is defined as:

$$
\operatorname{IRAS}=\sum_{i} \frac{A_{i}}{A_{\text {Lim }}},
$$

where $A_{i}$ is specific activity (in $\mathrm{Bq} / \mathrm{g}$ ) of radionuclide $i$ within a package, and $A_{\text {Lim }}$ is activity limit of radionuclide $i$. The activity of ETM, DTM and ITM nuclides are estimated with using different techniques. To make explicit the contribution to IRAS of each this family, Eq. (1) can be rewritten as follows [5]:

$$
I R A S=\sum_{l} \frac{A_{E T M, l}}{A_{\text {Lim }, l}}+\sum_{m} \frac{A_{D T M, m}}{A_{\text {Lim }, m}}+\sum_{n} \frac{A_{I T M, n}}{A_{L i m, n}} .
$$

The first summation accounts for specific activity of ETMs nuclides, which is based on direct measurement results. The second term includes contribution to DTMs nuclide sums, whose activity is determined with using SF method or MAM for the results including also the data below DL. And the third summation evaluates contribution to IRAS of calculated DTM nuclides from the number of nuclides ITM - all data below the DL.

The waste is accepted for final disposal if each package's IRAS is below 10 and weighted IRAS of the batch is below 1 :

$$
I R A S_{\text {batch }}=\frac{\sum_{j} I R A S_{j} \times M_{j}}{\sum_{j} M_{j}}<1,
$$

where $I R A S_{j}$ is package $j$ IRAS, and $M_{j}$ is its weight (in $\mathrm{kg}$ ).
A similar procedure is provided for in the criteria [3] for acceptance of ChNPP waste at Exclusion Zone territory. However, the latter does not provide for any analysis of individual radionuclide contributions to the sum (1), and comparison with some limit values, as it is done in the IRAS assessment. The contribution $C_{i}$ of a radionuclide $i$ to the IRAS is defined as:

$$
C_{i}=\frac{\frac{A_{i}}{A_{L i m, i}}}{\sum_{j} \frac{A_{j}}{A_{L i m, j}}} .
$$

If nuclide contribution to the IRAS is more than $1 \%$, ANDRA considers that it is necessary to measure it (direct ETM measurement and Scaling Factor application for DTMs), otherwise it is estimated with using Correlation Method (ITMs) [6]. Such a procedure allows revising the list of declared radionuclides and removing low-level radionuclides that do not impact the total activity of package.

In this study, above methodological approach was applied to assess the contribution to IRAS by following equation (4) of each radionuclide, whose activity shall be certified according to the acceptance criteria $[3,7]$. Since at the time of study [16] the list of controllable radionuclides in SRW was limited by document [3] requirements, the comparison with the values of new reference levels that are planned to be introduced in the near future [7] for a wider list of DTM nuclides was not carried out due to lack of measurement results for them.

To determine the contribution of each nuclide group to equation (2), the nuclides were split in manner like in previous chapter. The contribution of DTM (ITM) nuclides to IRAS package was estimated with using calculated values of their activity in the waste. Specific activity of DTM nuclide was identified by multiplying measured specific activity of $\mathrm{KN}$ in the waste $\left(\mathrm{A}_{\text {aver }}\right.$ and $\mathrm{A}_{\max }$ for ${ }^{137} \mathrm{Cs}$ or $\left.{ }^{60} \mathrm{Co}\right)$ by the value of corresponding SF established for ChNPP SRW in [16]. Thus, a software identification of DTM activity was simulated, provided in automated control systems based on the results of direct measurement of KN activities, e. g., with using gamma spectrometry method. Based on comparison of estimated value of contribution of each nuclide to the total IRAS with $1 \%$ threshold value, a new list of nuclides was compiled, which are subject to certification by direct measurement of activity (in a SRW package) or activity identification with using relevant calculation method. The total activity was estimated for a SRW mass equal to 6.444 tons. The test results were compared to the data obtained for all radionuclides subject to certification, without exception. 


\section{Results and Discussion}

Following the above methods methodology, for radionuclides subject to certification within the list and regulated by the requirements [3], the results presented in Tables 1-4 were obtained. The radionuclides in Tables 1 and 2 are arranged in the same order as in document [3].

Taking into account the fact that after repeated safety analysis of ChNPP SRW storage facility, the document [3] revision and its approval in new edition [7] were envisaged, the results obtained made it possible to evaluate the tested methods for the current and planned limits of radionuclide activities in packages. As can be seen from the Table 1, for some radionuclides, specific activity limits in [7] grew as compared to [3] (from 1.5 to 17.6 times, on average -5.3 times). For other nuclides, on the contrary, limit values have become more severe, and for some other, they sharply dropped by $4-6$ orders of magnitude. This is a crucial point in the discussion of results obtained, since the methodology of tested methods is mainly based on identification of list of radionuclides which shall be measured on the results of comparison of observable nuclide activity levels in the wastes with their limits allowable in the package for burial.

Unfortunately, the amount of experimental data on radionuclide specific activities in historical waste of ChNPP [16] was initially limited by the requirements of document [3]. For the same reason, analysis of results for extended list of nuclides, which is proposed to be certified according to [7], was impossible. The maximum values of levels of radionuclide specific activities in the wastes $\left(\mathrm{A}_{\max }\right)$ were also used to assess the compliance of IRAS values with the limits allowable for individual packages (up to 10) under their disposal in the compartments of waste storage facility.

Let's see the results of tested Method 1 presented in Table 1. According to its algorithm (see Fig. 2), we had to identify SF calculation options as based on the results of analyzed measured levels of specific activity of radionuclides in the waste, and to compare the DL values for DTM (ITM) nuclides to activity limits. Or, if DL is not beyond the established limits $\left(0.1 \mathrm{~A}_{\text {Lim }}\right.$, see in Table 1$)$, to assign 0 value for SF. It means that the presence of DTM nuclides in the waste can be neglected, and their activity should not be taken into account when identifying summary activity of the package.

As a result, all ITM radionuclides (all measurement results containing $\mathrm{A}<\mathrm{DL}$ ) without any exception, were not included in the list of those ones, whose activity shall be taken into account when identifying summary activity of the package. The following fact should be noted. The introduction of new, more severe activity limits brought only ${ }^{99} \mathrm{Tc}$ closer to the established limits. However, the
$\mathrm{DL}_{\mathrm{DTM}} / \mathrm{A}_{\mathrm{Lim}}$ ratio did not exceed recommended $10 \%$ barrier; therefore, the activity of this nuclide was not also taken into account in the Method 1. Nonzero SF values correspond to the data [16], which were calculated with using standard procedure for their establishment. As expected, as a result of this methodological approach, summary activity of SRW in package has dropped. Quantitative characteristics of this effect are given below (see Table 3 ) along with the evaluation results of applied other calculation methods.

The Table 2 shows the results of tested Method 2. Method 2 algorithm is built analogously to Method 1 algorithm, but uses other criteria to select the nuclides, whose activity in the waste shall be measured or calculated (with using SF or average activity method). The values of nuclide activity limits $\left(\mathrm{A}_{\text {Lim }}\right)$ are given in Table 1 . As expected, the list of nuclides subject to mandatory certification in historical waste has significantly changed. In terms of its composition, it also radically differs from the result of used Method 1 (see Table 1), since many nuclides were excluded because of their contribution to IRAS made less, than $1 \%$. For new Criteria edition [7] with stricter activity limits, this list turned out to be even narrower. The exceptions are ${ }^{137} \mathrm{Cs}$ and ${ }^{60} \mathrm{Co}$ nuclides, which, despite their scanty contribution to IRAS, cannot be excluded, since, first, they are $\mathrm{KN}$, and second, as shown below (see Table 4), their contribution to summary package activity can make from 50 to $93 \%$.

In addition to the above, it should be noted that the results shown in Table 2 for new revision of Criteria [7] are characterized by abnormally high contribution to the IRAS of ${ }^{99} \mathrm{Tc}$ radionuclide. It seems to us that this is a consequence of the fact that for ${ }^{99} \mathrm{Tc}$ the activity limit is set too low for ChNPP waste accepted for burial. As a result, even the absolute value of IRAS in waste package not only exceeded the value of 1 , but also approached its critical value (equal to 10) allowable for a separate package.

Critical analysis of new activity limits proposed in [7] was not addressed in this work. However, on the assumption that the specific activity limit in the package $\left(\mathrm{A}_{\text {Lim }}\right)$ for the above nuclide remains the same, we performed an alternative IRAS estimate. As a result, for each radionuclide, its contribution to IRAS was overestimated. In Table 2, the results of realized alternative assessment are given in brackets, but for those radionuclides only, whose contribution to IRAS has significantly changed, and became of order above $1 \%$. Even visually, it is possible to assess how the results of alternative assessment differ fundamentally from the previous assessment version, both in the number of nuclides requiring certification and in their relative contribution to the IRAS. Moreover, as it can be seen from the Table. 2, total IRAS decreased to an acceptable value and did not exceed $1(0,36$ for 
Table 1. Results of applied Method 1 algorithm

\begin{tabular}{|c|c|c|c|c|c|c|c|}
\hline \multirow{2}{*}{ Nuclide } & \multirow{2}{*}{$\begin{array}{c}\mathrm{A}_{\max }{ }^{*} \text { or }<\mathrm{DL}, \\
\mathrm{Bq} / \mathrm{g}\end{array}$} & \multicolumn{2}{|c|}{$\mathrm{A}_{\mathrm{Lim}}, \mathrm{Bq} / \mathrm{g}$} & \multicolumn{2}{|c|}{$A_{\max }$ or DL, in $\%$ from $A_{\text {Lim }}$} & \multirow{2}{*}{$\begin{array}{l}\text { Comparison } \\
\text { result }\end{array}$} & \multirow{2}{*}{ SF value } \\
\hline & & From [3] & From [7] & For [3] & For [7] & & \\
\hline${ }^{90} \mathrm{Sr}$ & $1.3 \cdot 10^{2}$ & $2.88 \cdot 10^{5}$ & $3.50 \cdot 10^{6}$ & $4.5 \cdot 10^{-2}$ & $3.7 \cdot 10^{-3}$ & $\mathrm{~A}_{\mathrm{DTM}}>\mathrm{DL}_{\mathrm{DTM}}$ & $2.9 \cdot 10^{-1}$ \\
\hline${ }^{93} \mathrm{Zr}$ & $<8.6 \cdot 10^{-2}$ & $3.85 \cdot 10^{3}$ & $6.76 \cdot 10^{4}$ & $2.2 \cdot 10^{-3}$ & $1.3 \cdot 10^{-4}$ & $\mathrm{DL}_{\mathrm{ITM}}<0.1 \mathrm{~A}_{\text {Lim }}$ & 0.0 \\
\hline${ }^{94} \mathrm{Nb}$ & $9.5 \cdot 10^{-1}$ & $2.08 \cdot 10^{3}$ & 7.77 & $4.6 \cdot 10^{-2}$ & $1.2 \cdot 10^{1}$ & $\mathrm{~A}_{\mathrm{DTM}}>\mathrm{DL}_{\mathrm{DTM}}$ & $1.1 \cdot 10^{-1}$ \\
\hline${ }^{99} \mathrm{Tc}$ & $<5.8 \cdot 10^{-1}$ & $4.17 \cdot 10^{3}$ & $1.61 \cdot 10^{1}$ & $1.4 \cdot 10^{-2}$ & 3.6 & $\mathrm{DL}_{\mathrm{ITM}}<0.1 \mathrm{~A}_{\mathrm{Lim}}$ & 0.0 \\
\hline${ }^{129} \mathrm{I}$ & $<6.0 \cdot 10^{-3}$ & $9.09 \cdot 10^{1}$ & $6.37 \cdot 10^{1}$ & $6.6 \cdot 10^{-3}$ & $9.4 \cdot 10^{-3}$ & $\mathrm{DL}_{\mathrm{ITM}}<0.1 \mathrm{~A}_{\text {Lim }}$ & 0.0 \\
\hline${ }^{135} \mathrm{Cs}$ & $<0.1$ & $8.07 \cdot 10^{3}$ & $1.40 \cdot 10^{3}$ & $1.2 \cdot 10^{-3}$ & $7.1 \cdot 10^{-3}$ & $\mathrm{DL}_{\mathrm{ITM}}<0.1 \mathrm{~A}_{\mathrm{Lim}}$ & 0.0 \\
\hline${ }^{137} \mathrm{Cs}$ & $4.8 \cdot 10^{2}$ & $7.78 \cdot 10^{5}$ & $1.96 \cdot 10^{6}$ & $6.2 \cdot 10^{-2}$ & $2.4 \cdot 10^{-2}$ & $\mathrm{~A}_{\mathrm{ETM}}>\mathrm{DL}_{\mathrm{ETM}}$ & $1.0(\mathrm{KN})$ \\
\hline${ }^{235} \mathrm{U}$ & $6.7 \cdot 10^{-4}$ & 3.51 & 6.66 & $1.9 \cdot 10^{-2}$ & $1.0 \cdot 10^{-2}$ & $\mathrm{~A}_{\mathrm{DTM}}>\mathrm{DL}_{\mathrm{DTM}}$ & $5.9 \cdot 10^{-4}$ \\
\hline${ }^{236} \mathrm{U}$ & $<2.2 \cdot 10^{-3}$ & $1.54 \cdot 10^{2}$ & $4.39 \cdot 10^{2}$ & $1.4 \cdot 10^{-3}$ & $5.0 \cdot 10^{-4}$ & $\mathrm{DL}_{\mathrm{ITM}}<0.1 \mathrm{~A}_{\mathrm{Lim}}$ & 0.0 \\
\hline${ }^{238} \mathrm{U}$ & $1.4 \cdot 10^{-2}$ & 1.37 & 3.40 & 1.0 & $4.1 \cdot 10^{-1}$ & $\mathrm{~A}_{\mathrm{DTM}}>\mathrm{DL}_{\mathrm{DTM}}$ & $1.9 \cdot 10^{-4}$ \\
\hline${ }^{237} \mathrm{~Np}$ & $<2.4 \cdot 10^{-2}$ & 9.54 & $1.99 \cdot 10^{1}$ & $2.5 \cdot 10^{-1}$ & $1.2 \cdot 10^{-1}$ & $\mathrm{DL}_{\mathrm{ITM}}<0.1 \mathrm{~A}_{\text {Lim }}$ & 0.0 \\
\hline${ }^{238} \mathrm{Pu}$ & $<2.9 \cdot 10^{-2}$ & $5.35 \cdot 10^{2}$ & $7.03 \cdot 10^{3}$ & $5.4 \cdot 10^{-3}$ & $4.1 \cdot 10^{-4}$ & $\mathrm{DL}_{\mathrm{ITM}}<0.1 \mathrm{~A}_{\mathrm{Lim}}$ & 0.0 \\
\hline${ }^{239} \mathrm{Pu}$ & $<2.1 \cdot 10^{-2}$ & $4.80 \cdot 10^{1}$ & $1.38 \cdot 10^{2}$ & $4.9 \cdot 10^{-2}$ & $1.5 \cdot 10^{-2}$ & $\mathrm{DL}_{\mathrm{ITM}}<0.1 \mathrm{~A}_{\mathrm{Lim}}$ & 0.0 \\
\hline${ }^{240} \mathrm{Pu}$ & $<7.7 \cdot 10^{-2}$ & $4.91 \cdot 10^{1}$ & $1.43 \cdot 10^{2}$ & $1.6 \cdot 10^{-1}$ & $5.4 \cdot 10^{-2}$ & $\mathrm{DL}_{\text {ITM }}<0.1 \mathrm{~A}_{\text {Lim }}$ & 0.0 \\
\hline${ }^{241} \mathrm{Pu}$ & $<1.8 \cdot 10^{-1}$ & $2.53 \cdot 10^{3}$ & $1.08 \cdot 10^{4}$ & $7.1 \cdot 10^{-3}$ & $1.7 \cdot 10^{-3}$ & $\mathrm{DL}_{\mathrm{ITM}}<0.1 \mathrm{~A}_{\mathrm{Lim}}$ & 0.0 \\
\hline${ }^{242} \mathrm{Pu}$ & $<1.3 \cdot 10^{-3}$ & $5.00 \cdot 10^{1}$ & $1.48 \cdot 10^{2}$ & $2.6 \cdot 10^{-3}$ & $8.8 \cdot 10^{-4}$ & $\mathrm{DL}_{\mathrm{ITM}}<0.1 \mathrm{~A}_{\mathrm{Lim}}$ & 0.0 \\
\hline${ }^{241} \mathrm{Am}$ & 5.1 & $8.76 \cdot 10^{1}$ & $3.73 \cdot 10^{2}$ & 5.8 & 1.4 & $\mathrm{~A}_{\mathrm{DTM}}>\mathrm{DL}_{\mathrm{DTM}}$ & $1.8 \cdot 10^{-2}$ \\
\hline${ }^{243} \mathrm{Am}$ & $<0.1$ & $5.42 \cdot 10^{1}$ & $8.12 \cdot 10^{1}$ & $1.8 \cdot 10^{-1}$ & $1.2 \cdot 10^{-1}$ & $\mathrm{DL}_{\mathrm{ITM}}<0.1 \mathrm{~A}_{\mathrm{Lim}}$ & 0.0 \\
\hline${ }^{14} \mathrm{C}$ & $1.8 \cdot 10^{-1}$ & $1.30 \cdot 10^{7}$ & $5.31 \cdot 10^{1}$ & $1.4 \cdot 10^{-6}$ & $3.4 \cdot 10^{-1}$ & $\mathrm{~A}_{\mathrm{DTM}}>\mathrm{DL}_{\mathrm{DTM}}$ & $2.8 \cdot 10^{-1}$ \\
\hline${ }^{3} \mathrm{H}$ & 3.6 & $3.77 \cdot 10^{15}$ & $5.11 \cdot 10^{14}$ & $9.5 \cdot 10^{-14}$ & $7.1 \cdot 10^{-13}$ & $\mathrm{~A}_{\mathrm{DTM}}>\mathrm{DL}_{\mathrm{DTM}}$ & $8.0 \cdot 10^{-2}$ \\
\hline${ }^{10} \mathrm{Be}$ & $<0.5$ & $2.50 \cdot 10^{6}$ & $1.59 \cdot 10^{4}$ & $2.0 \cdot 10^{-5}$ & $3.1 \cdot 10^{-3}$ & $\mathrm{DL}_{\mathrm{ITM}}<0.1 \mathrm{~A}_{\mathrm{Lim}}$ & 0.0 \\
\hline${ }^{59} \mathrm{Ni}$ & $<1.0$ & $5.90 \cdot 10^{7}$ & $3.82 \cdot 10^{4}$ & $1.7 \cdot 10^{-6}$ & $2.6 \cdot 10^{-3}$ & $\mathrm{DL}_{\mathrm{ITM}}<0.1 \mathrm{~A}_{\mathrm{Lim}}$ & 0.0 \\
\hline${ }^{63} \mathrm{Ni}$ & $<1.0$ & $1.90 \cdot 10^{8}$ & $4.91 \cdot 10^{5}$ & $5.3 \cdot 10^{-7}$ & $2.0 \cdot 10^{-4}$ & $\mathrm{DL}_{\mathrm{ITM}}<0.1 \mathrm{~A}_{\mathrm{Lim}}$ & 0.0 \\
\hline${ }^{60} \mathrm{Co}$ & 5.9 & $-^{* *}$ & $1.00 \cdot 10^{17}$ & - & $5.9 \cdot 10^{-15}$ & $\mathrm{~A}_{\mathrm{ETM}}>\mathrm{DL}_{\mathrm{ETM}}$ & $1.0(\mathrm{KN})$ \\
\hline
\end{tabular}

Note. ${ }^{*}-\mathrm{A}_{\max }$ according to laboratory control results [16]. ${ }^{*}$ - specific and total activity of ${ }^{60} \mathrm{Co}$ is not standardized by document [3], but is subject to declaration in certificate for package being sent for burial. KN is the designation of a key nuclide for which SF value is conventionally assumed to be equal to 1.0 . 
Table 2. Assessment of IRAS for historical waste package from the ChNPP and contribution of nuclides to its value for two versions of Criteria for waste accepted for burial

\begin{tabular}{|c|c|c|c|c|c|c|c|c|}
\hline \multirow{4}{*}{$\begin{array}{l}\text { Nuclide } \\
\text { or IRAS }\end{array}$} & \multicolumn{8}{|c|}{ Contribution to IRAS of nuclides subject to certification in waste packaging } \\
\hline & \multicolumn{4}{|c|}{$\mathrm{A}_{\text {Lim }}$ according to [3] } & \multicolumn{4}{|c|}{$\mathrm{A}_{\text {Lim }}$ according to $[7]^{*}$} \\
\hline & \multicolumn{2}{|c|}{ Calculation for $\mathrm{A}_{\text {aver }}$} & \multicolumn{2}{|c|}{ Calculation for $\mathrm{A}_{\max }$} & \multicolumn{2}{|c|}{ Calculation for $\mathrm{A}_{\text {aver }}$} & \multicolumn{2}{|c|}{ Calculation for $\mathrm{A}_{\max }$} \\
\hline & rel. units & $\%$ & rel. units & $\%$ & rel. units & $\%$ & rel. units & $\%$ \\
\hline${ }^{90} \mathrm{Sr}$ & $2.3 \cdot 10^{-4}$ & $3,3 \cdot 10^{-2}$ & $4.8 \cdot 10^{-4}$ & $3.3 \cdot 10^{-2}$ & $1.9 \cdot 10^{-5}$ & $5.2 \cdot 10^{-4}$ & $4.0 \cdot 10^{-5}$ & $5.2 \cdot 10^{-4}$ \\
\hline${ }^{93} \mathrm{Zr}$ & $1.1 \cdot 10^{-4}$ & $1.6 \cdot 10^{-2}$ & $8.6 \cdot 10^{-4}$ & $5.9 \cdot 10^{-2}$ & $6.4 \cdot 10^{-6}$ & $1.7 \cdot 10^{-4}$ & $4.9 \cdot 10^{-5}$ & $6.4 \cdot 10^{-4}$ \\
\hline${ }^{94} \mathrm{Nb}$ & $4.1 \cdot 10^{-5}$ & $5.8 \cdot 10^{-3}$ & $3.1 \cdot 10^{-4}$ & $2.1 \cdot 10^{-2}$ & $1.1 \cdot 10^{-2}$ & $0.3(3.1)$ & $8.4 \cdot 10^{-2}$ & $1.1(10.1)$ \\
\hline${ }^{99} \mathrm{Tc}$ & $1.3 \cdot 10^{-2}$ & 1.8 & $2.6 \cdot 10^{-2}$ & 1.8 & 3.3 & $90.6(3.6)$ & 6.9 & $89.5(3.2)$ \\
\hline${ }^{129} \mathrm{I}$ & $6.1 \cdot 10^{-3}$ & 0.9 & $1.3 \cdot 10^{-2}$ & 0.9 & $8.7 \cdot 10^{-3}$ & $0.2(\mathbf{2 . 4})$ & $1.8 \cdot 10^{-2}$ & $0.2(\mathbf{2 . 2})$ \\
\hline${ }^{135} \mathrm{Cs}$ & $1.1 \cdot 10^{-3}$ & 0.2 & $2.3 \cdot 10^{-3}$ & 0.2 & $6.4 \cdot 10^{-3}$ & $0.2(1.8)$ & $1.3 \cdot 10^{-2}$ & 0.2 \\
\hline${ }^{137} \mathrm{Cs}$ & $2.9 \cdot 10^{-4}$ & $4.2 \cdot 10^{-2}$ & $6.2 \cdot 10^{-4}$ & $4.2 \cdot 10^{-2}$ & $1.2 \cdot 10^{-4}$ & $3.2 \cdot 10^{-3}$ & $2.4 \cdot 10^{-4}$ & $3.2 \cdot 10^{-3}$ \\
\hline${ }^{235} \mathrm{U}$ & $1.3 \cdot 10^{-4}$ & $1.8 \cdot 10^{-2}$ & $9.9 \cdot 10^{-4}$ & $6.8 \cdot 10^{-2}$ & $6.8 \cdot 10^{-5}$ & $1.9 \cdot 10^{-3}$ & $5.2 \cdot 10^{-4}$ & $6.8 \cdot 10^{-3}$ \\
\hline${ }^{236} \mathrm{U}$ & $5.7 \cdot 10^{-3}$ & 0.8 & $1.2 \cdot 10^{-2}$ & 0.8 & $2.0 \cdot 10^{-3}$ & $5.5 \cdot 10^{-2}$ & $4.2 \cdot 10^{-3}$ & $5.4 \cdot 10^{-2}$ \\
\hline${ }^{238} \mathrm{U}$ & $3.2 \cdot 10^{-2}$ & 4.5 & $6.6 \cdot 10^{-2}$ & 4.5 & $1.3 \cdot 10^{-2}$ & $0.4(3.6)$ & $2.7 \cdot 10^{-2}$ & $0.3(3.2)$ \\
\hline${ }^{237} \mathrm{~Np}$ & $2.3 \cdot 10^{-1}$ & 32.4 & $4.7 \cdot 10^{-1}$ & 32.4 & $1.1 \cdot 10^{-1}$ & $3.0(30.6)$ & $2.3 \cdot 10^{-1}$ & $2.9(27.4)$ \\
\hline${ }^{238} \mathrm{Pu}$ & $4.7 \cdot 10^{-3}$ & 0.7 & $9.9 \cdot 10^{-3}$ & 0.7 & $3.6 \cdot 10^{-4}$ & $9.9 \cdot 10^{-3}$ & $7.5 \cdot 10^{-4}$ & $9.8 \cdot 10^{-3}$ \\
\hline${ }^{239} \mathrm{Pu}$ & $3.9 \cdot 10^{-2}$ & 5.6 & $8.2 \cdot 10^{-2}$ & 5.6 & $1.4 \cdot 10^{-2}$ & $0.4(3.9)$ & $2.8 \cdot 10^{-2}$ & $0.4(3.5)$ \\
\hline${ }^{240} \mathrm{Pu}$ & $1.4 \cdot 10^{-1}$ & 20.1 & $2.9 \cdot 10^{-1}$ & 20.1 & $4.8 \cdot 10^{-2}$ & $1.3(13.6)$ & $1.0 \cdot 10^{-1}$ & $1.3(12.2)$ \\
\hline${ }^{241} \mathrm{Pu}$ & $6.5 \cdot 10^{-3}$ & 0.9 & $1.4 \cdot 10^{-2}$ & 0.9 & $1.5 \cdot 10^{-3}$ & $4.2 \cdot 10^{-2}$ & $3.2 \cdot 10^{-3}$ & $4.2 \cdot 10^{-2}$ \\
\hline${ }^{242} \mathrm{Pu}$ & $1.0 \cdot 10^{-2}$ & 1.4 & $2.1 \cdot 10^{-2}$ & 1.4 & $3.4 \cdot 10^{-3}$ & $\begin{array}{c}9.4 \cdot 10^{-2} \\
(\mathbf{0 . 9})\end{array}$ & $7.1 \cdot 10^{-3}$ & $\begin{array}{c}9.3 \cdot 10^{-2} \\
(\mathbf{0 . 9})\end{array}$ \\
\hline${ }^{241} \mathrm{Am}$ & $4.7 \cdot 10^{-2}$ & 6.8 & $9.8 \cdot 10^{-2}$ & 6.7 & $1.1 \cdot 10^{-2}$ & $0.3(3.1)$ & $2.3 \cdot 10^{-2}$ & $0.3(\mathbf{2 . 8})$ \\
\hline${ }^{243} \mathrm{Am}$ & $1.6 \cdot 10^{-1}$ & 23.7 & $3.4 \cdot 10^{-1}$ & 23.7 & $1.1 \cdot 10^{-1}$ & $3.1(31.1)$ & $2.3 \cdot 10^{-1}$ & $3.0(27.9)$ \\
\hline${ }^{14} \mathrm{C}$ & $1.7 \cdot 10^{-8}$ & $2.4 \cdot 10^{-6}$ & $1.3 \cdot 10^{-7}$ & $8.7 \cdot 10^{-6}$ & $4.1 \cdot 10^{-3}$ & $0.1(\mathbf{1 . 2})$ & $3.1 \cdot 10^{-2}$ & $0.4(3.8)$ \\
\hline${ }^{3} \mathrm{H}$ & $4.9 \cdot 10^{-15}$ & $6.9 \cdot 10^{-13}$ & $1.0 \cdot 10^{-14}$ & $6.9 \cdot 10^{-13}$ & $3.6 \cdot 10^{-14}$ & $9.9 \cdot 10^{-13}$ & $7.5 \cdot 10^{-14}$ & $9.8 \cdot 10^{-13}$ \\
\hline${ }^{10} \mathrm{Be}$ & $7.4 \cdot 10^{-7}$ & $1.1 \cdot 10^{-4}$ & $5.6 \cdot 10^{-6}$ & $3.9 \cdot 10^{-4}$ & $1.2 \cdot 10^{-4}$ & $3.2 \cdot 10^{-3}$ & $8.9 \cdot 10^{-4}$ & $1.2 \cdot 10^{-2}$ \\
\hline${ }^{59} \mathrm{Ni}$ & $6.1 \cdot 10^{-8}$ & $8.8 \cdot 10^{-6}$ & $4.7 \cdot 10^{-7}$ & $3.2 \cdot 10^{-5}$ & $9.5 \cdot 10^{-5}$ & $2.6 \cdot 10^{-3}$ & $7.3 \cdot 10^{-4}$ & $9.5 \cdot 10^{-3}$ \\
\hline${ }^{63} \mathrm{Ni}$ & $1.9 \cdot 10^{-8}$ & $2.7 \cdot 10^{-6}$ & $1.5 \cdot 10^{-7}$ & $1.0 \cdot 10^{-5}$ & $7.4 \cdot 10^{-6}$ & $2.0 \cdot 10^{-4}$ & $5.6 \cdot 10^{-5}$ & $7.4 \cdot 10^{-4}$ \\
\hline${ }^{60} \mathrm{Co}$ & - & - & - & - & $7.7 \cdot 10^{-18}$ & $2.1 \cdot 10^{-16}$ & $5.9 \cdot 10^{-17}$ & $7.7 \cdot 10^{-16}$ \\
\hline IRAS & 0.7 & & 1.5 & & $3.6(0.4)$ & & $7.7(0.8)$ & \\
\hline
\end{tabular}

Note. ${ }^{\star}$ - Results of alternative variant of assessed radionuclides contribution to IRAS are given in brackets. 
Table 3. Evaluation of tested methods in comparison with the standard procedure for assessing radionuclide total activity in waste packages and laboratory control data

\begin{tabular}{|c|c|c|c|c|c|c|c|c|}
\hline \multirow{3}{*}{$\begin{array}{l}\text { Compared } \\
\text { parameter }\end{array}$} & \multicolumn{8}{|c|}{ Calculation method and variant } \\
\hline & \multicolumn{2}{|c|}{ Standard method } & \multicolumn{2}{|c|}{ Method 1} & \multicolumn{2}{|c|}{ Method 2} & \multicolumn{2}{|c|}{ On laboratory data } \\
\hline & $\mathrm{A}_{\text {aver }}$ & $\mathrm{A}_{\max }$ & $A_{\text {aver }}$ & $A_{\max }$ & $A_{\text {aver }}$ & $\mathrm{A}_{\max }$ & $\mathrm{A}_{\text {aver }}$ & $A_{\max }$ \\
\hline $\begin{array}{c}\text { Total } \\
\text { activity, } \mathrm{Bq}\end{array}$ & $2.79 \cdot 10^{9}$ & $6.20 \cdot 10^{9}$ & $2.06 \cdot 10^{9}$ & $4.35 \cdot 10^{9}$ & $\begin{array}{c}1.99 \cdot 10^{9 \star} \\
1.94 \cdot 10^{9 \star *} \\
2.05 \cdot 10^{9 * \star *}\end{array}$ & $\begin{array}{l}4.17 \cdot 10^{9 \star} \\
4.09 \cdot 10^{9 \star *} \\
4.32 \cdot 10^{9 \star \star \star}\end{array}$ & $1.59 \cdot 10^{9}$ & $4.03 \cdot 10^{9}$ \\
\hline K1 & 1.00 & 1.00 & 1.35 & 1.43 & $\begin{array}{c}1.40^{*} \\
1.43^{\star *} \\
1.36^{* * *}\end{array}$ & $\begin{array}{l}1.49^{\star} \\
1.52^{\star \star} \\
1.44^{* \star}\end{array}$ & 1.75 & 1.54 \\
\hline $\mathrm{K} 2$ & 1.75 & 1.54 & 1.29 & 1.08 & $\begin{array}{c}1.25^{\star} \\
1.22^{\star *} \\
1.29^{\star * \star}\end{array}$ & $\begin{array}{c}1.04^{\star} \\
1.01^{\star *} \\
1.07^{\star * *}\end{array}$ & 1.00 & 1.00 \\
\hline
\end{tabular}

Note. $\mathrm{K} 1$ - relation to calculation result according to the standard procedure. K2 - relation to calculation result according to laboratory control data of representative samples. ${ }^{\star}$ - Results for V5 versions of the Criteria [3]. ${ }^{\star \star}$ - Results for V6 versions of the Criteria [7]. $* * *$ - Alternative assessment results for V6 versions of the Criteria [7].

$\mathrm{A}_{\text {aver }}$ and 0,83 for $\left.\mathrm{A}_{\max }\right)$. Such a circumstance, in our opinion, indicates that under the above-mentioned assumptions about ${ }^{99} \mathrm{Tc}$, the list of most significant radionuclides for ChNPP historical waste appears more preferable and adequate.

The results of Methods 1 and 2 tested on the assessment of total radionuclide activity in the package were compared to the results of applied standard calculation procedure ("standard method") based on used SF, and to the results of summed radionuclide activity in representative waste samples according to laboratory control data. As the Table 3 demonstrates, each of calculation algorithms was applied for two versions of initial data $\left(1-\right.$ for average specific activity $A_{\text {aver }}$ and $2-$ for maximum specific activity $\mathrm{A}_{\max }$ of radionuclides in waste). The Table 4 shows assessment results of structure of summary activity of waste in a package as based on the contribution of different nuclides groups to its value.

When comparing the data given in Table 3 , an unambiguous conclusion can be made as regards: the tested Methods 1 and 2 not only significantly reduce conservatism degree of calculated value of total radionuclide activity in a package (see parameter K1), but also significantly bring its value closer to laboratory control data (see parameter K2). Moreover, this effect is most pronounced when used in the assessment of maximum levels of $\mathrm{KN}$ activities in the waste. The list of nuclides subject to certification has also radically changed. At the same time, as Table 4 shows, if Method 1 practically completely excludes ITM nuclides from the determination of total activity of package, then Method 2, on the contrary, forms a more
Table 4. The contribution of nuclide group to total activity of a SRW package, $\%$

\begin{tabular}{|c|c|c|c|c|c|c|c|c|}
\hline \multirow{3}{*}{$\begin{array}{c}\text { Group } \\
\text { of } \\
\text { nuclide }\end{array}$} & \multicolumn{8}{|c|}{ Calculation method and variant } \\
\hline & \multicolumn{2}{|c|}{$\begin{array}{l}\text { Standard } \\
\text { method }\end{array}$} & \multicolumn{2}{|c|}{ Method 1} & \multicolumn{2}{|c|}{ Method 2} & \multicolumn{2}{|c|}{$\begin{array}{c}\text { On } \\
\text { laboratory } \\
\text { data }\end{array}$} \\
\hline & $\mathrm{A}_{\text {aver }}$ & $A_{\text {max }}$ & $\mathrm{A}_{\text {aver }}$ & $\mathrm{A}_{\text {max }}$ & $\mathrm{A}_{\text {aver }}$ & $\mathrm{A}_{\max }$ & $\mathrm{A}_{\text {aver }}$ & $\mathrm{A}_{\text {max }}$ \\
\hline ETM & 53.3 & 50.5 & 72.0 & 72.0 & $\begin{array}{c}74.9^{\star} \\
76.5^{\star \star} \\
72.5^{\star \star \star}\end{array}$ & $\begin{array}{c}75.0^{\star} \\
76.6^{\star *} \\
72.5^{\star * *}\end{array}$ & 93.3 & 77.2 \\
\hline DTM & 20.7 & 19.6 & 28 & 28 & $\begin{array}{c}1.3^{\star} \\
0.0^{\star \star} \\
1.4^{\star * \star} \\
\end{array}$ & $\begin{array}{c}1.4^{\star} \\
0.1^{\star *} \\
1.7^{\star * *} \\
\end{array}$ & 5.2 & 22.2 \\
\hline ITM & 26.0 & 29.9 & 0.0 & 0.0 & $\begin{array}{c}23.8^{\star} \\
23.5^{\star *} \\
26.0^{\star * *}\end{array}$ & $\begin{array}{c}23.6^{\star} \\
23.3^{\star *} \\
25.8^{\star * *}\end{array}$ & 1.5 & 0.6 \\
\hline
\end{tabular}

Note. ${ }^{*}$ - Results for V5 versions of the Criteria [3]. ${ }^{*}$ - Results for V6 versions of the Criteria [7]. ${ }^{* *}$ - Alternative assessment results for V6 versions of the Criteria [7].

balanced list of nuclides based on the contribution of DTM (ITM) nuclides in summary package IRAS.

\section{Conclusions}

The use of quantitative criteria proposed in the tested methods allows significantly reducing overestimation degree of total activity of a package due to removal from the 
list of difficult-to-measure radionuclides, whose presence of activity in the wastes can be neglected in terms of negligible risk for exceeding their established activity limits.

The methods addressed in this work, which are based on used quantitative criteria, optimize the content of radionuclides subject to mandatory measurement or calculated determination of their activity in waste packages, and which can be recommended to solve existing problems with the characterization of low-level historical waste from Chornobyl Nuclear Power Plant being transported for burial.

When the data are available on activity levels of radionuclides, which were not included in the consideration within this work framework, repeated analysis of tested methods efficiency shall be conducted with using extended list of nuclides planned to be certified in accordance with the requirements of new revision of Acceptance Criteria [7]. In our opinion, it would be very useful to supplement the text of new Criteria revision with a term analogous in its content to IRAS notion, which is used in RAW management system at the territory of France.

\section{References}

1. OECD (2017). Radiological characterization from a waste and materials. end-state perspective: practices and experience (NEA-7373). Nuclear Energy Agency of the OECD (NEA), 100 p. Available at: https://www.oecd-nea.org/ rwm/pubs/2017/7373-rad-char-pers.pdf.

2. Determination and use of scaling factors for waste characterization in NPP. IAEA Nuclear Energy Series NW-T-1.18. Vienna: IAEA, 2009, 142 p.

3. Criteria for acceptance of waste for burial in specially equipped near-surface repository for solid radwaste (SESRSRW). First stage of SESRSRW operation. Acceptance of RAW from SSE ChNPP PTLRW and PTSRW for burial in two symmetrical compartments of SESRSRW. Revision 5. Endorsed by acting Director General of State Corporation “UkrSE 'Radon'”. Chornobyl, 2009, 38 p. (in Ukr.)

4. Mykhailov O. V., Bezmylov V. M., Terzi A. K. (2020). Analysis of radionuclide contamination features in solid radwaste of "light" eastern compartment of solid waste repository of Chornobyl NPP. Yaderna Energetyka ta Dovkillia [Nuclear Power and the Environment], vol. 16, no. 1, pp. 40-48.

5. Zaffora B., Magistris M., Saporta G., Chevalier J. (2017). Uncertainty quantification applied to the radiological characterization of radioactive waste. Applied Radiation and Isotopes, vol. 127, pp. 142-149. doi: 10.1016/j.apradiso.2017.06.001.

6. Zaffora B., Magistris M., Chevalier J., Luccioni C., Saporta G., Ulrici L. (2017). A new approach to characterize very-low-level radioactive waste produced at hadron accel- erators. Applied Radiation and Isotopes, vol. 122, 141-147. doi: 10.1016/j.apradiso.2017.01.019.

7. Criteria for acceptance of waste for burial in specially equipped near-surface repository for solid radwaste (SESRSRW). KRIII.109-4.023.-2018. Revision 6. Project. Endorsed by acting Director SSE “CERWM”. Chornobyl, 2018, 39 p. (in Ukr.).

8. Strategy and methodology for radioactive waste characterization. IAEA-TECDOC-1537. IAEA, VIENNA, 2007, 182 p.

9. ISO 21238:2007 Nuclear energy - Nuclear fuel technology - Scaling factor method to determine the radioactivity of low- and intermediate-level radioactive waste packages generated at nuclear power plants. Geneva: International Organization for Standardization, 2007.

10. ISO 16966:2013 Nuclear energy - Nuclear fuel technology - Theoretical activation calculation method to evaluate the radioactivity of activated waste generated at nuclear reactors. Geneva: International Organization for Standardization, 2013.

11. Lukauskas D., Plukiene R., Plukis A., Gudelis A., Duskesas G., Juodis L., Druteikiene R., Lujaniene G., Luksiene B., Remeikis V. (2006). Method to determine the nuclide inventory of low-activity waste of the RBMK-1500 reactor. Lithuanian J. Phys., vol. 46, no. 4, pp. 497-503. doi: 10.3952/lithjphys.46413.

12. Plukis A., Remeikis V., Juodis L., Plukiene R., Lukauskas D., Gudeli A. (2008). Analysis of nuclide content in Ignalina NPP radioactive waste streams. Lithuanian J. of Phys., vol. 48, no. 4, pp. 375-379. doi: 10.3952/lithjphys.48409.

13. Mykhailov O. V., Krasnov V. O., Bezmylov V. M. (2019). Theoretical and Practical Aspects in Using Scaling Factor Method to Characterize Operational Solid Radioactive Waste Producible at Nuclear Power Plants. Yaderna Energetyka ta Dovkillia [Nuclear Power and the Environment], vol. 13 , no. 1 , pp. 52-58.

14. Albertone L., Altavilla M., Marga M., Porzio L., Tozzi G., Tura P. (2019). Control Experiences Regarding Clearable Materials from Nuclear Power Plants and Nuclear Installations: Scaling Factors Determination and Measurements' Acceptance Criteria Definition. Environments, vol. 11, no. 6, p. 120. doi:10.3390/environments6110120.

15. Zaffora B., Magistris M., Saporta G., La Torre F. (2016). Statistical sampling applied to the radiological characterization of historical waste. EPJ Nuclear Sci. Technol., vol. 2., no. 34, pp. 1-11. doi: 10.1051/epjn/2016031.

16. Mikhailov A. V., Pavljuchenko N. I., Mjasnikov A. V., Terzi A. K., Krasnov V. A. (2019). [Results of radionuclide vectors determination to be used in characterization of SSE NPP's solid radwaste]. Problemy Chornobyl'skoi zony vidchuzhennia [Problems of Chornobyl exclusion zone], vol. 20, pp. 13-26. (in Russ.) 
17. Maksymenko A. M., Bondarkov M. D., Oskolkov B. Ya., Seida V. A., Dubas V. N. (2019). [Results for Studies of Hard-toMeasure Radionuclides in the Metal of Chornobyl Nuclear Power Plant Equipment being Dismantled, and Estimation of Scaling Factor]. Yaderna Energetyka ta Dovkillia [Nuclear Power and the Environment], vol. 13, no. 1, pp. 67-75. (in Russ.)

18. ISO 11929 Determination of the Characteristic Limits (Decision Threshold, Detection Limit and Limits of the Confidence Interval) for Measurements of Ionizing Radiation-Fundamentals and Application. Geneva, Switzerland: International Standard Organization, 2019.

\section{О. В. Михайлов, В. М. Безмилов}

Інститут проблем безпеки АЕС НАН України, вул. Кірова, 36а, Чорнобиль, 07270, Украӥна,

\section{Щодо нових методичних підходів з вирішення проблеми паспортизації історичних твердих радіоактивних відходів Чорнобильської АЕС, які направляються на захоронення}

Діючі в зоні відчуження правила передачі й остаточного захоронення радіоактивних відходів (РАВ) вимагають оцінки та паспортизації активності радіонуклідів у кожній упаковці з відходами відповідно до затвердженого переліку. Ця інформація використовується Оператором сховища для контролю запасів і активності радіонуклідів, які зазвичай обмежуються оцінкою безпеки сховища та наявною ліцензією на його експлуатацію. Для оптимального вирішення питань, пов’язаних із паспортизацією радіонуклідного складу РАВ в упаковках, що спрямовуються на захоронення, Міжнародне агентство з атомної енергії (МАГАТЕ) рекомендує використовувати методологію радіонуклідних векторів (Scaling Factors methodology). Однак під час її реалізації виникли певні труднощі, особливо в частині визначення низьких рівнів активності радіонуклідів, що важко вимірюються (РВB), у так званих історичних РАВ, накопичених ще до аварії на Чорнобильській АЕС у 1986 р. Методи, які використовуються на сьогодні, дозволяють проводити лише консервативну оцінку вмісту РВВ у відходах, що в кінцевому підсумку призводить до істотного завищення їх сумарної активності в упаковках.

Останніми роками увага дослідників різних країн була направлена на підвищення ефективності методів радіологічної характеризації партій РАВ під час знят- тя з експлуатації ядерних установок та розробку алгоритмів визначення оптимального складу радіонуклідів, що підлягають сертифікації (паспортизації). Це сприяло 6 зниженню ступеня переоцінки сумарної активності в упаковках з відходами, які направляються на захоронення в сховища РАВ.

У роботі розглянуто два методичних підходи до сертифікації радіонуклідного складу, які використовуються в системах поводження з РАВ Італії та Франції. Перший з них - метод визначення коефіцієнтів масштабування для РВВ у відходах на основі порівняння виміряних рівнів питомої активності радіонуклідів, у тому числі у вигляді <МДА (мінімально детектованої активності), з їхніми граничними значеннями згідно з критеріями приймання на захоронення. Метод дозволяє виключити з розгляду $\mathrm{PBB}$ у разі, якщо його МДА знаходиться нижче певного значення, кратного встановленій межі активності (припустима питома активність в упаковці). Другий - методика оцінки прийнятності відходів і факторів їхньої небезпеки за величиною параметра IRAS (Radiological Acceptance Index in Storage). Метод дозволяє оптимізувати список нуклідів, що підлягають обов’язковому вимірюванню або розрахунковій оцінці їхньої активності у РАВ на основі кількісної оцінки внеску кожного з нуклідів, що мають бути задекларовані в паспорті, в сумарний IRAS упаковці.

За результатами проведеного дослідження встановлено, що застосування кількісних критеріїв, які використовуються в алгоритмах вивчених методичних підходів до сертифікації РАВ, дозволяє істотно знизити ступінь переоцінки сумарної активності упаковок з відходами за рахунок видалення зі списку РВВ, присутністю активності яких можна знехтувати $з$ точки зору мізерності ризику перевищення встановлених для них меж активності. Розглянуті в роботі методичні підходи дозволяють оптимізувати склад радіонуклідів, що підлягають обов’язковому вимірюванню або розрахунковому визначенню їхньої активності в упаковках відходів, і можуть бути рекомендовані для вирішення проблем з характеризацією історичних відходів Чорнобильської AEC, які направляються на захоронення.

Ключові слова: радіоактивні відходи,

Чорнобильська АЕС, питома активність, мінімально детектована активність, радіонукліди, що важко вимірюються, реперні радіонукліди, сертифікація, коефіцієнт масштабування.

Надійшла 28.10.2020

Received 28.10.2020 